УДК 615.32:633.888.271]-08:547.586.5/.972.2

DOI https://doi.org/10.11603/2312-0967.2020.1.10983

\title{
ВПЛИВ КОНЦЕНТРАЦІї ЕТАНОЛУ В ЕКСТРАГЕНТІ НА ФЛАВОНОЇДНИЙ ПРОФІЛЬ ВИТЯГУ ІЗ ЛИСТЯ ШОВКОВИЦІ БІЛОЇ І ЙОГО ЦУКРОЗНИЖУВАЛЬНУ ДІЮ
}

\author{
Л. В. Вронська, А. І. Дуб, А. Є. Демид, Т. А. Грошовий, І. М. Кліщ \\ Тернопільський національний медичний університет імені І. Я. Горбачевського \\ мОЗ України \\ vronska_liudmyla@ukr.net
}

ІНФОРМАЦІЯ

Надійшла до редакції / Received: 30.01.2020

Після доопрацювання / Revised: 12.02.2020

Прийнято до друку / Accepted: 20.02.2020

\section{Ключові слова:}

листя шовковиці білої;

рідкі витяги;

сухий екстракт;

фрлавоноїди;

концентрація етанолу;

цукрознижувальна дія.

\section{АНОТАЦІЯ}

Мета роботи. Вивчення фрлавоноїдного профріля спиртових витягів і цукрознижувальної дії сухого екстракту листя шовковиці білої залежно від концентрації етанолу в екстрагенті.

Матеріали і методи. Матеріал дослідження - рідкі витяги, отримані методом дробної мацерації 3 листя шовковиці білої за допомогою спиртових розчинів із вмістом етанолу 10-95 \% (об/об), співвідношення сировини до екстрагенту 1:10, кратність екстрагування - 5, тривалість одного екстрагування - 24 год; витяги згущували в ротаційному випарювачі і висушували при температурі $45-50{ }^{\circ} \mathrm{C}$. Вивчення фрлавоноїдного профріля здійснювали хроматографічними методами, кількісний вміст фрлавоноїдів визначали спектрофротометрично, вміст сухого залишку - гравіметрично. Вивчення цукрознижувальної дії екстрактів проводили на білих щурах (модель «глюкозного навантаження»).

Результати й обговорення. Якісні дослідження спиртових витягів листя шовковиці білої, здійснені методами ТШХ і ВЕРХ, дозволили ідентифрікувати рутин, ізокверцитрин, кемпорерол-3-О-глюкозид і кверцитрин (мала кількість). Якісний склад є практично незмінним, що пов'язано із розчинністю глікозидів фрлавоноїдів у широкому інтервалі концентрацій етанолу. Встановлено, що зростання вмісту етанолу в екстрагенті від 40 до 80 \% (об/об), приводить до підвищення екстракції фрлавоноїдів. Екстрагенти із вмістом етанолу 4080 \% (об/об) дозволяють отримувати рідкі витяги 3 практично однаковим сухим залишком (2 \%). Екстрагенти із вмістом етанолу 70-80 \% (об/об) забезпечують найвище вилучення фрлавоноїдів за інших однакових умов (1,17-1,24 мг/мл у перерахунку на рутин, спектрофотометрично). Сухі екстракти, отримані за допомогою екстрагентів із вмістом етанолу 60-90 \% (об/об), показали здатність істотно знижувати рівень глюкози в крові тварин під час «глюкозного навантаження».

Висновки. Хроматографічний профріль спиртових витягів із листя шовковиці білої містить рутин, ізокверцитрин, кемпферол-3-О-глюкозид і кверцитрин. 3 підвищенням концентрації етанолу в екстрагенті зростає вміст фрлавоноїдів, а екстрагенти із вмістом етанолу 70-80 \% (об/об) є найбільш ефективними для вилучення фрлавоноїдів. Сухі екстракти, отримані на основі досліджуваних витягів, істотно знижують рівень глюкози в крові тварин в експерименті на моделі «глюкозного навантаження». 
Вступ. Листя шовковиці білої в традиційній китайській медицині застосовується при лікуванні цукрового діабету, для зниження артеріального тиску, як гепатопротектор та ін., а також досліджується 3 приводу різних видів активності [1-10]. Кожен вид дії зумовлює присутність як окремих сполук, так і комплекс біологічно активних речовин [1, 3, 4, 7-12]. Листя містить поліфенольні сполуки, фрлавоноїди, гідроксикоричні кислоти, жирні кислоти, полісахариди, інгібітор а-глюкозидази - DNJ (1-деоксиноїриміцин) та ін. [1, 3, 13-15]. Серед інших біологічно активних речовин цієї сировини виділяють фрлавоноїди, яким характерна висока антиоксидантна активність, а в комплексі 3 іншими речовинами, - цукрознижувальна, гіполіпідемічна дія [1, 3, 7-10, 12]. Разом з цим, більшість досліджень пов'язана із вивченням активності виділених та ідентиорікованих сполук і поодинокі дослідження присвячені вивченню екстрактів, отриманих в умовах, наближених до промислового виробництва [1]. Недостатнім $€$ дослідження впливу виду екстрагента на активність екстрактів, отримуваних із листя шовковиці білої, зокрема, екстрагентів, придатних для промислового виробництва екстрактів - різних водно-етанольних розчинів.

Тому метою роботи є вивчення фрлавоноїдного профріля спиртових витягів і цукрознижувальної дії сухого екстракту листя шовковиці білої залежно від концентрації етанолу в екстрагенті.

Матеріали і методи. Об'єкт дослідження вплив концентрації етанолу в екстрагенті на склад і вміст фрлавоноїдів у спиртових витягах листя шовковиці білої та цукрознижувальну дію отримуваних із цих витягів сухих екстрактів. Матеріал дослідження - рідкі витяги, отримані методом дробної мацерації з листя шовковиці білої вітчизняного походження за допомогою спиртових розчинів із вмістом етанолу 10-95 \% (об/об), використане співвідношення сировини до екстрагента 1:10, кратність екстрагування - 5, тривалість одного екстрагування - 24 год. Отримані спиртові витяги згущували в ротаційному випарювачі і висушували при температурі $45-50{ }^{\circ} \mathrm{C}$.

Вивчення складу фрлавоноїдів здійснювали методами тонкошарової (ТШХ) і високоефективної рідинної хроматографрії (BEPX), оцінку сумарного вмісту фрлавоноїдів - спектрофотометричним методом. Вміст сухого залишку в отримуваних спиртових витягах визначали гравіметрично [16].

ТШХ-дослідження здійснювали за допомогою нерухомої фрази - Silica gel $60 \mathrm{~F}_{254}$ (хроматографрічні пластинки «Merck», Німеччина) і двох рухомих фраз: мурашина кислота - вода - етилацетат (6:9:90), мурашина кислота - льодяна оцтова кислота - вода етилацетат (7.5:7.5:17:67.5); нанесення досліджуваних витягів здійснювали за допомогою приладу для нанесення проб Linomat 5 («CAMAG», Швейцарія).
Проявлення фрлавоноїдів на ТШХ-хроматограмах здійснювали послідовно метанольним розчином 10 г/л аміноетилового ефріру дифенілборної кислоти, а після висушування - метанольним розчином 50 г/л макроголу 400. Для ідентифікації фрлавоноїдів використовували стандартні зразки рутину, гіперозиду, апігенін-7-глюкозиду, лютеолін-7-глюкозиду, ізокверцитрину, кверцитрину, лютеоліну, кверцетину, кемпферолу, кемпферол-3-О-глюкозиду (SigmaAldrich, Fluka). При ВEPX-дослідженні фрлавоноїдів застосовували рідинний хроматографр Agilent 12003 детектором діодною матрицею («Agilent», США). Умови хроматографування і детектування детально описані [17].

Кількісний вміст фрлавоноїдів визначали спектрофотометричним методом, вимірюючи поглинання комплексу фрлавоноїдів з алюміній хлоридом [18] в середовищі 70 \% (об/об) етанолу.

Вивчення цукрознижувальної дії екстрактів проводили на білих нелінійних щурах-самцях масою $(200 \pm 20)$ г 3 нормальним вуглеводним гомеостазом, який оцінювали за базальним рівнем глікемії і за зміною рівня глюкози внаслідок виконання орального тесту толерантності до глюкози. Попередньо тварини піддавались 8-годинному голодуванню. Всі тварини були розділені на групи: 0 контрольна група, яка отримувала воду очищену; 1 - група «глюкозного навантаження» (ГН), тварини якої отримували 40 \% розчин глюкози в перерахунку 3 г/кг маси тварини, внутрішньошлунково; 2 - 6 дослідні групи (ГН + E), які за 1 годину до введення глюкози отримували водний розчин відповідного сухого екстракту (у дозі 200 мг/кг), отриманого за допомогою екстрагентів із вмістом етанолу 50-90 \% (об/об). Цукрознижувальну дію оцінювали як здатність знижувати рівень глюкози в крові тварин після «глюкозного навантаження». Для цього розраховували відсоток зростання рівня глюкози в крові тварин групи ГН (1) і дослідних груп ГН + E (2-6) порівняно із рівнем глюкози в крові тварин контрольної групи (0 група). Вміст глюкози в крові тварин визначали за допомогою тестсмужок і глюкометра «Accu-Chek performa» (Roche Diagnostics, Німеччина). Забір крові здійснювали шляхом дистальної резекції хвоста піддослідних тварин через 30, 60, 90, 120 і 180 хв після введення водного розчину глюкози. Всі експерименти із залученням лабораторних тварин проводили, керуючись нормами біоетики, які рекомендуються Європейською конвенцією про захист хребетних тварин, що використовуються для дослідних та інших наукових цілей (Страсбург, 1986), Директивою Європейського Союзу 2010/10/63 EU щодо експериментів на тваринах, рекомендаціями «Біоетична експертиза доклінічних та інших наукових досліджень, що виконуються на тваринах» (Київ, 2006) i законом України «Про захист тварин від жорстоко-

ISSN 2312-0967. Фармацевтичний часопис. 2020. № 1 
го поводження» (Відомості Верховної Ради України, 2006 (із змінами)).

Результати й обговорення. Результати хроматографрічного дослідження, здійсненого методами BEPX і ТШХ, вказують на значний вплив концентрації етанолу в екстрагенті на екстрагування орлавоноїдів. На рисунку 1 представлені зображення хроматограм спиртових витягів із листя шовковиці білої, отриманих за допомогою екстрагентів із вмістом етанолу 50-90 \% (об/об) в обраних системах розчинників при нанесенні однієї і тієї ж кількості витягу. Із зростанням вмісту етанолу в екстрагенті підвищується ефрективність вилучення фрлавоноїдів - на отриманих хроматограмах виявляються зони оранжево-жовтої (група глікозидів кверцетину, мірицетину) і жовто-салатової (група глікозидів кемпореролу) фллуоресценції і зростає розмір зони та її інтенсивність. У хроматографрічних профрілях витягів, отриманих за допомогою екстрагентів із вмістом етанолу 50 \% (об/об), виявляється чітка зона жовто-салато-
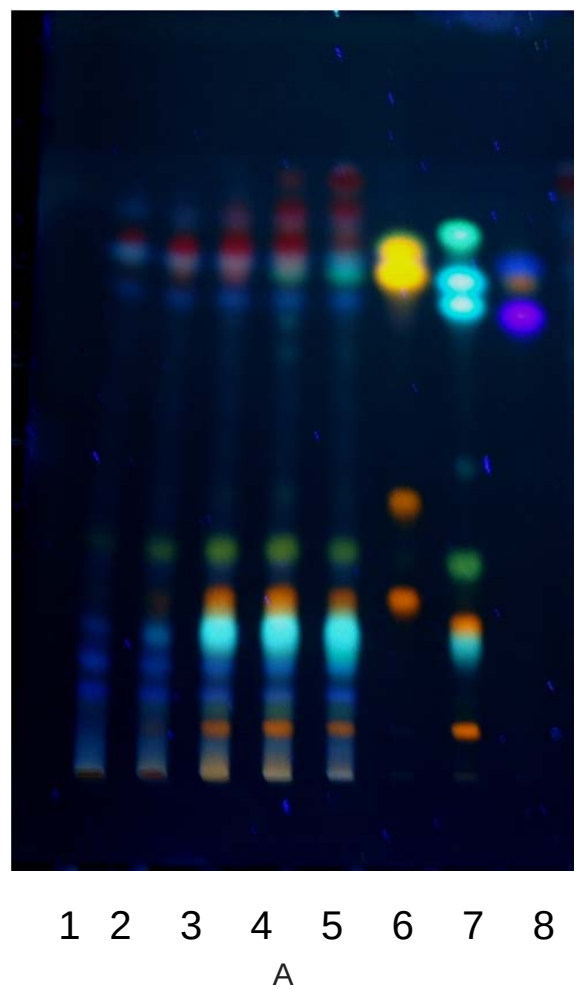

вої фрлуоресценції, яка за розташуванням у профрілях із двома системами розчинників ідентиорікується як кемпферол-3-О-глюкозид. Проте цей екстрагент, якй випливає з вигляду хроматограсрічного профрілю витягу (рис. 1, А), ще не забезпечує ефективне екстрагування фрлавоноїдів, порівняно з екстрагентами із вищим вмістом етанолу. Підвищення його вмісту $60 \%$ (об/об) в екстрагенті супроводжується появою зон рутину та ізокверцитрину, розмір зон та інтенсивність фрлуоресценції яких зростають із підвищенням вмісту етанолу до 70-80 \% (об/об). Слабкі зони кверцитрину з'являються у просрілях витягів, отриманих за допомогою екстрагентів із вмістом етанолу 70 і 80 \% (об/об). Отже, у хроматографрічних профрілях отриманих витягів в обраних системах розчинників ідентифікуються як зони оранжевої фрлуоресценції: рутин, кверцитрин, ізокверцитрин, а як зона салатово-жовтої фрлуоресценції - кемпферол-3О-глюкозид. При лінії старту, в системі розчинників мурашина кислота - вода - етилацетат (6:9:90),

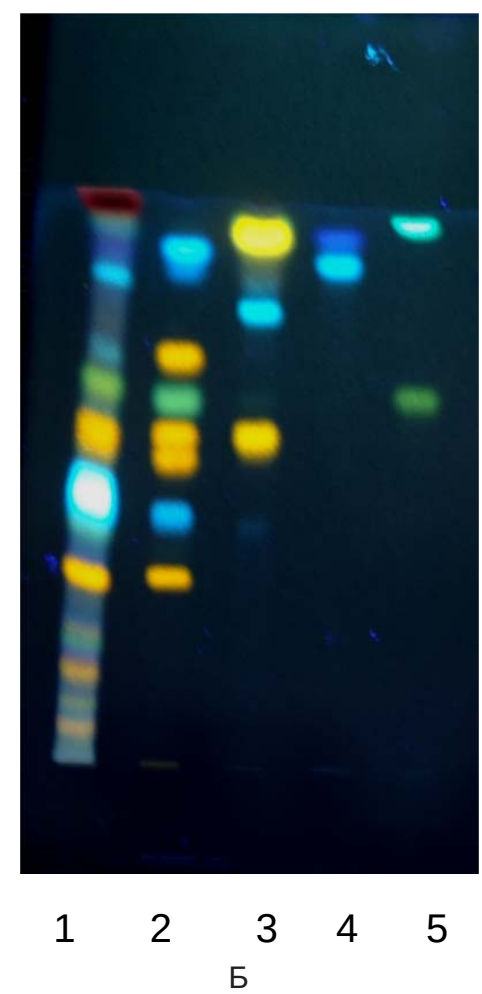

Рис. 1. Хроматограми спиртових витягів із листя шовковиці білої в системах розчинників: А - мурашина кислота - вода - етилацетат (6:9:90), Б - мурашина кислота - льодяна оцтова кислота - вода - етилацетат

(7.5:7.5:17:67.5). Хроматограма A: 1-5 - треки витягів, отримані за допомогою екстрагентів із вмістом етанолу 50-90 \% (об/об) відповідно; 6 - трек стандартного розчину речовин: ізокверцитрин, кверцитрин, кверцетин, лютеолін; 7 - трек стандартного розчину речовин: рутин, хлорогенова кислота, гіперозид, апігенін-7-глюкозид, розмаринова кислота, кофейна кислота, кемпферол; 8 - трек стандартного розчину речовин: галова кислота, мірицетин, ферулова кислота. Хроматограма Б: 1 - трек витягу, отриманого за допомогою екстрагента з вмістом етанолу 80 \% (об/об); 2 - трек стандартного розчину речовин: рутин, хлорогенова кислота, гіперозид, ізокверцитрин, апігенін-7-глюкозид, кверцитрин, косейна кислота;

3 - трек стандартного розчину речовин: ізокверцитрин, цикорієва кислота, лютеолін; 4 - трек стандартного розчину речовин: розмаринова кислота, фрерулова кислота; 5 - трек стандартного розчину речовин: кемпферол-3-О-глюкозид, кемпферол.

ISSN 2312-0967. Pharmaceutical review. 2020. № 1 
залишаються нерозділеними речовини, які проявляються оранжевою фрлуоресценцією. В системі розчинників мурашина кислота - льодяна оцтова кислота - вода - етилацетат (7.5:7.5:17:67.5) (хроматограма Б на рис. 1, отримана для витягу із вмістом етанолу в екстрагенті 80 \% (об/об), ці речовини розділилися і проявилися чотирма не ідентифікованими зонами, дві з яких характеризуються високою інтенсивністю фрлуоресценції. Ці речовини можуть бути поліглікозидами кверцетину чи глікозидами мірицетину як більш гідроксильованого фрлавонолу, ніж кверцетин. Саме через вищий ступінь гідроксилювання молекули мірицетин і його глікозиди характеризуються вищою розчинністю у воді, завдяки чому вони залишалися при лінії старту у більш неполярній системі розчинників (хроматограма A, рис. 1) і розділилися у більш полярній (хроматограма Б, рис. 1).

На рисунку 2 представлено ВЕРХ-хроматограму спиртового витягу з листя шовковиці білої, отриманого за допомогою екстрагента із вмістом етанолу 70 \% (об/об).

Аналіз даних, отриманих методом ВЕРX, підтверджує присутність рутину, ізокверцитрину, кемпоерол3-О-глюкозиду і кверцитрину (мала кількість) у спиртових витягах листя шовковиці білої. Для порівняльної оцінки впливу вмісту етанолу на їхнє екстрагування обмежилися порівнянням площ відповідних піків на BEPX-хроматограмах витягів (таблиця). Як випли- ває із наведених даних, кількість індивідувальних орлавоноїдів у вилученнях збільшувалася із зростанням вмісту етанолу в екстрагенті, й особливо високий вміст спостерігався при використанні екстрагентів із вмістом етанолу 70-90 \% (об/об).

Кількісну оцінку впливу вмісту етанолу на екстрагування фрлавоноїдів здійснювали на основі показника сумарного вмісту фрлавоноїдів. Спектрофотометричним методом було проаналізовано рідкі витяги, отримані за допомогою екстрагентів із різним вмістом етанолу. Рутин присутній у всіх досліджуваних витягах і тому був обраний як стандартна речовина для перерахунку суми фрлавоноїдів. Паралельно для кожного витягу визначали сухий залишок. Результати цих визначень представлені на рисунку 3. Екстрагенти із вмістом етанолу 40-80 \% дозволяють отримувати рідкі витяги $з$ практично однаковим сухим залишком (2 \%), тоді як вміст фрлавоноїдів у них різний, на що вказували також якісні дослідження, здійснені методами ТШХ і ВЕРХ. Екстрагенти із вмістом етанолу 70-80 \% (об/об) забезпечують найвище вилучення фрлавоноїдів за інших однакових умов.

Таким чином, з огляду на склад і вміст фрлавоноїдів в отриманих витягах, оптимальними екстрагентами $\epsilon$ розчини із вмістом етанолу 70-80 \% (об/об).

Для вивчення цукрознижувальної дії обрано витяги, отримані за допомогою екстрагентів із вмістом

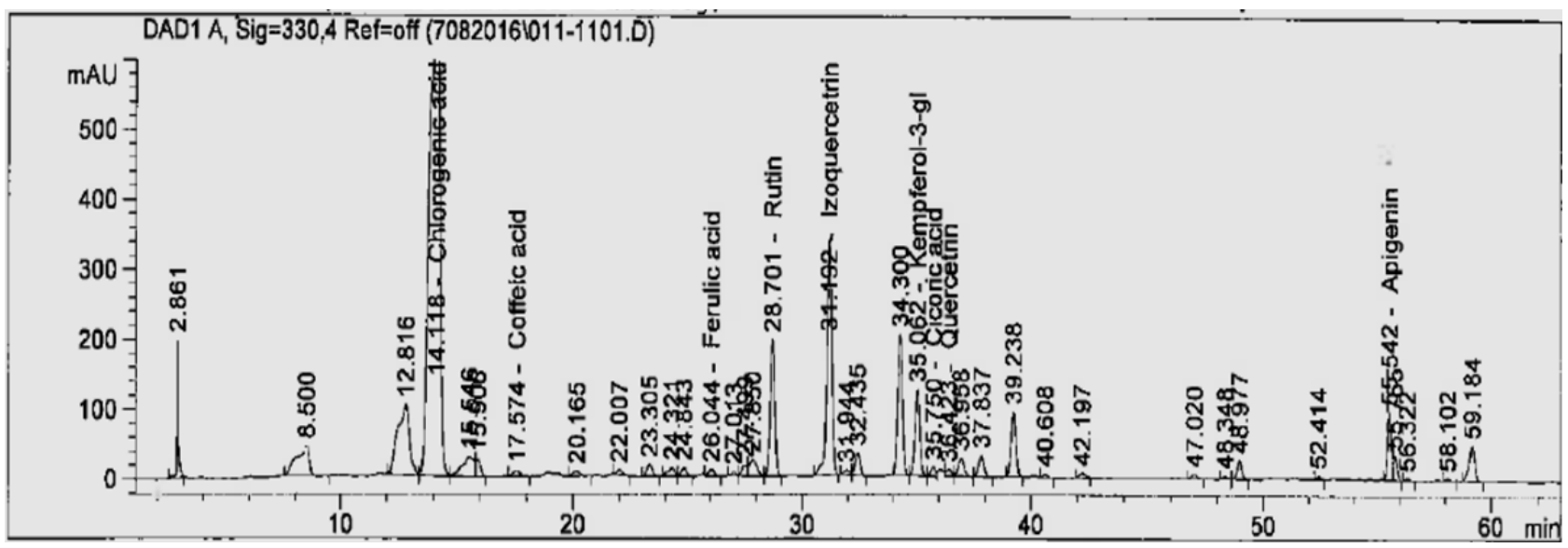

Рис. 2. Хроматограма спиртового витягу листя шовковиці білої (екстрагент - 70 \% (об/об) етанол). Довжина хвилі детектування 330 нм.

Таблиця

Вплив вмісту етанолу в екстрагенті на екстрагування біологічно активних речовин за даними BEPX-аналізу

\begin{tabular}{|l|c|c|c|c|c|}
\hline \multirow{2}{*}{ Речовина } & \multicolumn{5}{|c|}{ Площа піку (умовні одиниці) для речовини у витягах, отриманих за допомогою } \\
& \multicolumn{5}{|c|}{ екстрагентів із вмістом етанолу (\%, (об/об)) } \\
\cline { 2 - 6 } & 50 & 60 & 70 & 80 & 90 \\
\hline Рутин & 72,58 & 214,76 & 2789,46 & 3863,53 & 1863,74 \\
\hline Ізоквецитрин & 66,41 & 451,65 & 5159,80 & 7148,64 & 3393,96 \\
\hline Кемпсрерол-3-О-глюкозид & 95,97 & 729,70 & 2679,69 & 3473,67 & 1752,55 \\
\hline Кверцитрин & 15,16 & 42,14 & 90,26 & 125,13 & 98,23 \\
\hline
\end{tabular}

ISSN 2312-0967. Фармацевтичний часопис. 2020. № 1 
Фітохімічні дослідження Phytochemical researches

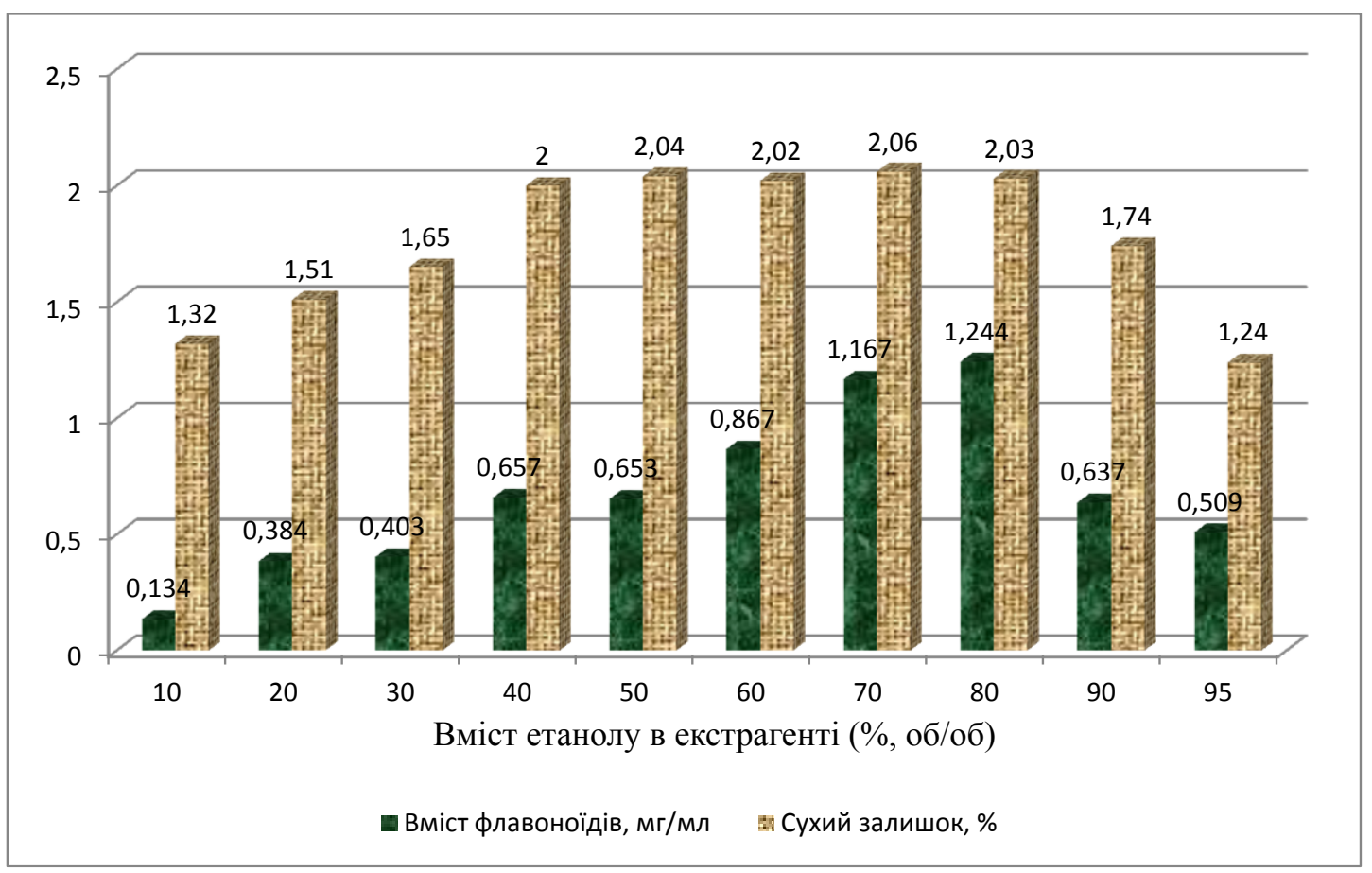

Рис. 3. Залежність кількісних показників рідкого витягу листя шовковиці білої від вмісту етанолу в ектрагенті.

етанолу 50-90 \% (об/об), що характеризувалися вищим вмістом орлавоноїдів. Щоб уникнути застосування спиртових розчинів при вивченні цукрознижувальної дії на моделі «глюкозного навантаження», з рідких витягів листя шовковиці білої було отримано сухі екстракти. Впродовж 3 год вивчали динаміку рівня глюкози в крові всіх груп тва- рин. Для порівняльної оцінки цукрознижувальної дії отриманих сухих екстрактів листя шовковиці білої розраховували відсоток зростання рівня глюкози в крові тварин 1-6 груп порівняно із рівнем глюкози в крові тварин контрольної групи. Результати дослідження і відповідних розрахунків представлені на рисунку 4.

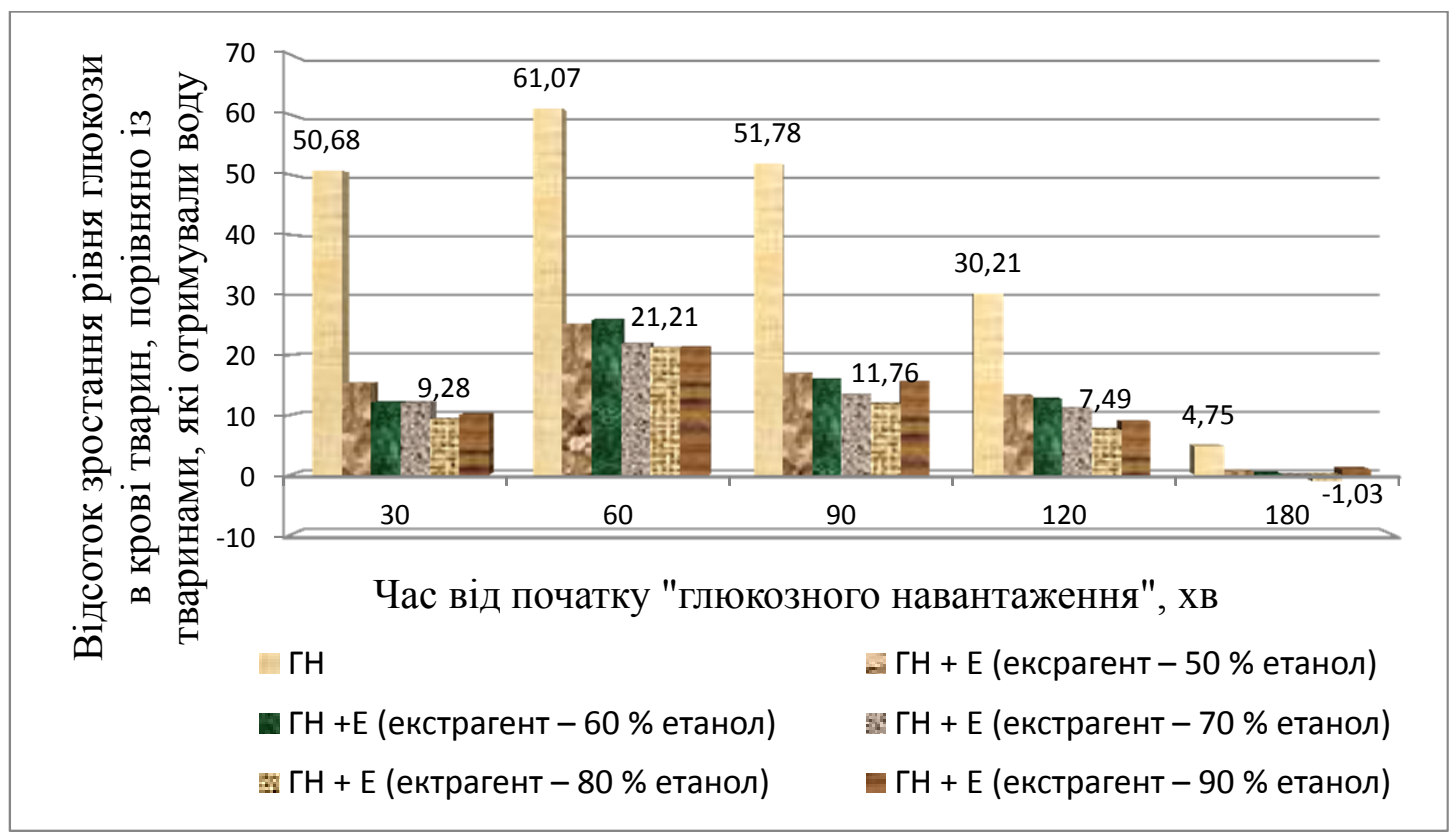

Рис. 4. Динаміка рівня глюкози в крові тварин при вивченні цукрознижувальної дії сухих екстрактів листя шовковиці білої на моделі «глюкозного навантаження».

ISSN 2312-0967. Pharmaceutical review. 2020. № 1 
Як випливає із представлених даних, сухі екстракти листя шовковиці білої, отримані за допомогою екстрагентів із вмістом етанолу 50-90 \% (об/об), виявляють цукрознижувальну дію. Визначення рівня глюкози в крові тварин у всіх часових інтервалах вимірювання вказує на його значне зниження під впливом біологічно активних речовин екстрактів. Кращу, порівняно з іншими, цукрознижувальну дію забезпечують екстракти, отримані за допомогою екстрагентів із вмістом етанолу 70-80\% (об/об). В крові тварин групи «глюкозного навантаження» вміст глюкози через три години спостереження ще перевищував рівень глюкози в крові тварин контрольної групи, тоді як застосування всіх екстрактів у цей період забезпечило зниження рівня глюкози до значень контрольної групи.

Таким чином, за інших однакових умов екстрагування використання екстрагента із вмістом етанолу 70-80\% (об/об) є оптимальним як із точки зору есрективності вилучення фллавоноїдів із сировини, так і з огляду на цукрознижувальну дію отриманого екстракту.

Висновки. Хроматографрічний профріль спиртових витягів із листя шовковиці білої містить рутин, ізокверцитрин, кемпферол-3-О-глюкозид і кверцитрин. 3 підвищенням концентрації етанолу в екстрагенті зростає вміст фрлавоноїдів, а екстрагенти із вмістом етанолу 70-80 \% (об/об) є найбільш ефективними для вилучення фрлавоноїдів. Сухі екстракти, отримані на основі цих витягів, істотно знижують рівень глюкози в крові тварин в експерименті на моделі «глюкозного навантаження». За інших однакових умов екстрагенти із вмістом етанолу 70-80 \% (об/об) $є$ оптимальними для отримання екстракту листя шовковиці білої з цукрознижувальною дією.

Конфолікт інтересів: відсутній.

Conflicts of interest: authors have no conflict of interest to declare.

\title{
THE INFLUENCE OF THE ETHANOL CONTENT IN THE EXTRACTANT ON FLAVONOIDS PROFILE OF THE MULBERRY WHITE LEAVES EXTRACTS AND ITS SUGAR-LOWERING EFFECT
}

\author{
L. V. Vronska, A. I. Dub, A. Ye. Demyd, T. A. Hroshovyi, I. M. Klishch \\ I. Horbachevsky Ternopil National Medical University \\ vronska_liudmyla@ukr.net
}

The aim of the work. The studying of the flavonoids profile of the mulberry white leaves alcohol extracts and the sugarlowering effect of its dry extract depending on the ethanol concentration in the extractant.

Materials and Methods. Material for research - liquid extracts obtained by fractional maceration of white mulberry leaves with alcoholic solutions containing 10-95\% (v/v) of the ethanol, the ratio of raw material to extractant 1:10, multiplicity extraction -5 , one extraction duration - 24 hours; the extracts were concentrated in a rotary evaporator and dried at $45-50{ }^{\circ} \mathrm{C}$. The study of the flavonoids profile was performed by chromatographic methods, the quantitative content of flavonoids was determined by spectrophotometric method, the content of the dry residue - by gravimetric method.

Results and Discussion. Qualitative studies of alcoholic extracts of the white mulberry leaves, carried out by TLC and HPLC, allowed us to identify the rutin, isoquercitrin, kaempferol-3-O-glucoside and quercitrin (small amount). The qualitative composition is practically unchanged due to the flavonoids glycosides solubility in a wide range of ethanol concentrations. It was established, that the increase of ethanol content in the extractant from 40 to $80 \%(\mathrm{v} / \mathrm{v})$, leads to increased of the flavonoids extraction. Extractants containing 40-80\% (v/v) of the ethanol allow to obtain liquid extracts with almost the same dry residue (2\%). Extractants with the ethanol content of $70-80 \%(\mathrm{v} / \mathrm{v})$ provide the highest extraction of flavonoids under other identical conditions (1.17-1.24 mg / $\mathrm{ml}$ in terms of rutin, spectrophotometric method). The dry extracts obtained with the extractants with the ethanol content of 60-90\% (v/v) showed the ability to significantly reduce glucose level in the blood of animals during "glucose load".

Conclusions. The chromatographic profile of the alcoholic extracts from the mulberry white leaves contains rutin, isoquercitrin, kaempferol-3-O-glucoside and quercitrin. With increasing of the ethanol concentration in the extractant, the content of flavonoids increases, and the extractants with the ethanol content of $70-80 \%(v / v)$ are the most effective for the extraction of flavonoids. The dry extracts obtained on the investigated extracts basis the significantly reduce the glucose level in the blood of the animals in the "glucose load" experiment.

Key words: mulberry white leaves; liquid extracts; dry extract; flavonoids; ethanol content; sugar-lowering effect.

ISSN 2312-0967. Фармацевтичний часопис. 2020. № 1 


\title{
ВЛИЯНИЕ КОНЦЕНТРАЦИИ ЭТАНОЛА В ЭКСТРАГЕНТЕ НА ФЛАВОНОИДНЫЙ ПРОФИЛЬ ВЫТЯЖКИ ИЗ ЛИСТЬЕВ ШЕЛКОВИЦЫ БЕЛОЙ И ЕЕ САХАРОСНИЖАЮЩЕЕ ДЕЙСТВИЕ
}

\author{
Л. В. Вронска, А. И. Дуб, А. Е. Демыд, Т. А. Грошовый, И. Н. Клищ \\ Тернопольский национальный медицинский университет имени И. Я. Горбачевского МОз Украины \\ vronska_liudmyla@ukr.net
}

\begin{abstract}
Цель работы. Изучение фрлавоноидного профиля спиртовых вытяжек и сахароснижающего действия сухого экстракта листьев шелковицы белой в зависимости от концентрации этанола в экстрагенте.

Материалы и методы. Материал исследования - жидкие вытяжки, полученные методом дробной мацерации из листьев шелковицы белой с помощью спиртовых растворов с содержанием этанола 10-95 \% (об/об), соотношение сырья и экстрагента 1:10, кратность экстрагирования - 5, продолжительность одного экстрагирования - 24 ч; вытяжки сгущались в ротационном испарителе и сушились при температуре $45-50{ }^{\circ} \mathrm{C}$. Изучение фрлавоноидного профиля осуществляли хроматографическими методами, количественное содержание фрлавоноидов определяли спектрофотометрически, содержание сухого остатка - гравиметрически. Изучение сахароснижающего действия экстрактов проводили на белых крысах (модель «глюкозной нагрузки»).

Результаты и обсуждение. Качественные исследования спиртовых вытяжек листьев шелковицы белой, проведенные методами ТСХ и ВЭЖХ, позволили идентисицировать рутин, изокверцитрин, кемпорерол-3-Оглюкозид и кверцитрин (малое количество). Качественный состав является практически неизменным, что связано с растворимостью гликозидов фрлавоноидов в широком интервале концентраций этанола. Установлено, что увеличение содержания этанола в экстрагенте с 40 до 80 \% (об/об), приводит к повышению экстракции фрлавоноидов. Экстрагенты с содержанием этанола 40-80 \% (об/об) позволяют получать жидкие вытяжки с практически одинаковым сухим остатком (2\%). Экстрагенты с содержанием этанола 70-80 \% (об/об) обеспечивают высокое извлечение фрлавоноидов, при прочих равных условиях, (1,17-1,24 мг/мл в пересчете на рутин, спектросотометрически). Сухие экстракты, полученные с помощью экстрагентов с содержанием этанола 60-90% (об/об), оказались способными существенно снижать уровень глюкозы в крови животных во время «глюкозной нагрузки».

Выводы. Хроматографический профиль спиртовых вытяжек из листьев шелковицы белой содержит рутин, изокверцитрин, кемпоерол-3-О-глюкозид и кверцитрин. С повышением концентрации этанола в экстрагенте возрастает содержание фрлавоноидов, а экстрагенты с содержанием этанола 70-80 \% (об/об) являются наиболее эфрфективными для извлечения фрлавоноидов. Сухие экстракты, полученные на основе исследуемых вытяжек, существенно снижают уровень глюкозы в крови животных в эксперименте на модели «глюкозного нагрузки».
\end{abstract}

Ключевые слова: листья шелковицы белой; жидкие витяжки; сухой экстракт; фрлавоноиды; концентрация этанола; сахароснижающее действие.

\section{Список бібліографічних посилань}

1. Chlorogenic acid and rutin play a major role in the in vivo anti-diabetic activity of Morus alba leaf extract on type II diabetic rats. Hunyadi A., Martins A., Hsieh T. J. et al. Plos One. 2012. Vol. 7. Iss. 11. e50619.

2. Investigation of the antidiabetic activity of Morus alba leaf extract in vitro and in vivo. Hunyadi A., Liktor-Busa E., Balogh A. et al. Planta Med. 2010. Vol. 76. P098.

3. Grajek K., Wawro A., Pieprz yk-Kokocha D. Bioactivity of Morus Alba L. Extracts - An Overview. Int. J Pharm. Sci. Res. 2015. Vol. Iss. 68. P. 3110-3122.

4. Morus Alba Linn: A Phytopharmacological review. Bandna Devi, Neha Sharma, Dinesh Kumar, Kamal Jeet. Int. J Pharm. Pharm. Sci. 2013. Vol. 5. Iss. 2. P. 14-18.

5. Metabolic effects of mulberry leaves: exploring potential benefits in type 2 diabetes and hyperuricemia. Hunyadi A., Liktor-Busa E., Marki A. et al. Evidence-Based Complementary and Alternative Medicine. 2013. Article ID 948627. 10 p.

6. Mohammadi J., Prakash R. Naik. The histopathologic effects of Morus alba leaf extract on the pancreas of diabetic rats. Turkish Journal of Biology. Vol. 36. Iss. 2. P. 211-216.
7. Protective effect of mulberry flavonoids on sciatic nerve in alloxan-induced diabetic rats. Song-Tao Ma, DongLian Liu, Jing-Jing Deng, Yann- Juan Peng. Braz. J Pharm. Sci. [online]. 2014. Vol. 50. Iss.4. P. $765-771$.

8. Free radical scavenging activity and total phenolic and flavonoid contents of mulberry (Morus spp. L., Moraceae) extracts. Radojković M. M., Zeković Z. P., Vidović S. S. et al. Hem. Ind. 2012. Vol. 66. Iss. 4. P. 547-552.

9. Chemical characterization and antioxidative properties of Polish variety of Morus alba L. leaf aqueous extracts from the laboratory and pilot-scale processes. Flaczyk E., Kobus-Cisowska J., Przeor M. et al. Agric. Sci. 2013. Vol. Iss. 04. P. 141-147.

10. Antioxidant activities and polyphenol content of Morus alba leaf extracts collected from varying regions. Dong-Seon Kim, Young Min Kang, Wen Yi Jin et al. Biomedical Reports. 2014. Vol. 2. P. 675-680.

11. Jo S. P., Kim J. K., Lim Y. H. Antihyperlipidemic effects of stilbenoids isolated from Morus alba in rats fed a high-cholesterol diet. Food Chem. Toxicol. 2014. Iss. 65. P. 213-218.

ISSN 2312-0967. Pharmaceutical review. 2020. № 1 
12. Chemical constituents of Morus alba L. and their inhibitory effect on 3T3-L1 preadipocyte proliferation and differentiation. Y. Yang, X. Yang, B. Xu et al. Fitoterapia. 2014. Vol. 98. Iss. 10. P. 222-227.

13. Phytochemical profiles of different mulberry (Morus sp.) species from China. Song W., Wang H.-J., Bucheli P. et al. J Agric. Food Chem. 2009. Vol. 57. Iss. 19. P. 9133-9140.

14. Study of biologically active substances of White Mulberry leaves and their extracts. Vronska L., Demyd A., Dub A. et al. Plant - the source of research material: proceedings of the $5^{\text {th }}$ International Conference and Workshop, 21 - 24 Jun. 2017. Lublin: POLIHIMNIA, 2015. P. 167.

15. Вронська Л. В., Демид А. Є. Хроматографрічні профрілі фрлавоноїдів і гідроксикоричних кислот вітчизняних зразків лікарської рослинної сировини

\section{References}

1. Hunyadi A, Martins A, Hsieh TJ, Seres A, Zupko I. Chlorogenic acid and rutin play a major role in the in vivo anti-diabetic activity of Morus alba leaf extract on type II diabetic rats. Plos One. 2012;7(11): e50619. doi: 10.1371/journal.pone.0050619.

2. Hunyadi A, Liktor-Busa E, Balogh A, Hsieh T, Zupko I, Hohmann J. Investigation of the antidiabetic activity of Morus alba leaf extract in vitro and in vivo. Planta Med. 2010;76: P098. doi: 10.1055/s-0030-1264396.

3. Grajek K, Wawro A and Pieprzyk-Kokocha D. Bioactivity of Morus Alba L. Extracts - An Overview. Int J Pharm Sci Res 2015;6(8): 3110-22. doi: 10.13040/ IJPSR.0975-8232.6(8).3110-22.

4. Bandna Devi, Neha Sharma, Dinesh Kumar, Kamal Jeet. Morus Alba Linn: A Phytopharmacological review. Int J Pharm Pharm Sci. 2013;5(2): 14-8. doi: 10.1007/ springerreference_68974

5. Hunyadi A, Liktor-Busa E, Marki A, Martins A, Jedlinszki N, Hsieh TJ et al. Metabolic effects of mulberry leaves: Exploring potential benefits in type 2 diabetes and hyperuricemia. Evidence-Based Complementary and Alternative Medicine. 2013;Article ID 948627: 10 p. doi: $10.1155 / 2013 / 948627$.

6. Mohammadi J, Prakash R Naik. The histopathologic effects of Morus alba leaf extract on the pancreas of diabetic rats. Turkish Journal of Biology. 36(2): 211-6. doi: 10.3906/biy-1008-51.

7. Song-Tao Ma, Dong-Lian Liu, Jing-Jing Deng, YannJuan Peng. Protective effect of mulberry flavonoids on sciatic nerve in alloxan-induced diabetic rats. Braz $\mathrm{J}$ Pharm Sci [online]. 2014;50(4): 765-71. doi: 10.1590/ S1984-82502014000400012.

8. Radojković MM, Zeković ZP, Vidović SS, Kočar DD, Mašković PZ. Free radical scavenging activity and total phenolic and flavonoid contents of mulberry (Morus spp. L., Moraceae) extracts. Hem Ind. 2012; 66(4): 547-52. doi: 10.2298/HEMIND111111002R.

9. Flaczyk E, Kobus-Cisowska J, Przeor M, Korczak J, Remiszewski $\mathrm{M}$, Korbas $\mathrm{Eu}$ et al. Chemical characterization and antioxidative properties of Polish variety of Morus alba L. leaf aqueous extracts from лится шовковиці білої. Фармацевтичний часопис. 2019. № 2. С. 5-15.

16. Державна Фармакопея України: в 3 т. / Державне підприємство «Український науковий орармакопейний центр якості лікарських засобів». - 2-е вид. - Харків : Державне підприємство «Український науковий фрармакопейний центр якості лікарських засобів», 2014. Т. 1. 1128 с.

17. Vronska L. V., Chubka M. B., Demyd A. Ye. Development of phenolic compounds chromatographic identification in bilberry shoots. Фармац. часопис. 2015. № 3. C. 28-33.

18. Вронська Л. В. Розробка спектросоотометричної методики визначення фрлавоноїдів у пагонах чорниці звичайної. Фармацевтичний часопис. 2018. № 4. C. $49-56$.

the laboratory and pilot-scale processes. Agric Sci. 2013;04:141-7. doi: 10.4236/as.2013.45B026.

10. Dong-Seon Kim, Young Min Kang, Wen Yi Jin, Yoon-Young Sung, Goya Choi, Ho Kyoung Kim. Antioxidant activities and polyphenol content of Morus alba leaf extracts collected from varying regions. Biomedical Reports. 2014;2: 675-80. doi: 10.3892/br.2014.294.

11. Jo SP, Kim JK, Lim YH. Antihyperlipidemic effects of stilbenoids isolated from Morus alba in rats fed a highcholesterol diet. Food Chem Toxicol. 2014 Mar;65: 213-8. doi: 10.1016/j.fct.2013.12.040.

12. Yang $Y$, Yang $X, X u$ B, Zeng G, Tan J, He X, Hu C, Zhou Y. Chemical constituents of Morus alba L. and their inhibitory effect on 3T3-L1 preadipocyte proliferation and differentiation. Fitoterapia. 2014;98(10): 2227. doi: 10.1016/j.fitote.2014.08.010

13. Song W, Wang H-J, Bucheli P, Zhang P-F, Wei D-Z, $\mathrm{Lu}$ Y-H. Phytochemical Profiles of Different Mulberry (Morus sp.) Species from China. J Agric Food Chem. 2009;57(19):9133-40. doi: 10.1021/jf9022228.

14. Vronska L, Demyd A, Dub A, Hroshoviy T, Klishch I. Study of biologically active substances of White Mulberry leaves and their extracts. In: Anna Bogucka-Kocka, Grazyna Szymczak, Janusz Kocki, Ireneusz Sowa editors. Plant - the source of research material: Proceedings of the $5^{\text {th }}$ International Conference and Workshop, 2017 Jun 21 - 24; Lublin. Lublin: POLIHIMNIA; 2015.

15. Vronska LV, Demyd AY. [Flavonoids and hydroxycinnamic acids chromatographic profiles of domestic raw materials samples of mulberry white leaves]. Farm chasop. 2019;2: 5-15. doi: 10.11603/23120967.2019.2.10269. Ukrainian.

16. The State Pharmacopoeia of Ukraine: in 3 vol. Kharkiv: Ukrainian Scientific Pharmacopoeia Center of Quality of Medicinal Products. Ed.2. [Державна Фармакопея України: в 3 т. / ДП «Український науковий фрармакопейний центр якості лікарських засобів». 2-е вид.] Kharkiv: Ukrainian Scientific Pharmacopoeia Center of Quality of Medicinal Products. 2014; Ukrainian.

ISSN 2312-0967. Фармацевтичний часопис. 2020. № 1 
17. Vronska LV, Chubka MB, Demyd AYe. Development of phenolic compounds chromatographic identification in bilberry shoots. Farm chasop. 2015;3: 28-33. doi : 10.11603/2312-0967.2015.3.4951.
18. Vronska LV. [Development of spectrophotometric method of flavonoids determination in bilberry shoots]. Farm chasop. 2018;4: 49-56. doi: 10.11603/23120967.2018.4.9703. Ukrainian.

\section{Відомості про авторів}

Вронська Л. В. - канд. хім., н., доцент кафедри фрармації, Тернопільський національний медичний університет імені І. Я. Горбачевського, Тернопіль, Україна. E-mail: vronska_liudmyla@ukr.net, ORCID 0000-0002-7223-6966.

Дуб А. І. - аспірант, асистент кафедри управління та економіки фрармації з технологією ліків, Тернопільський національний медичний університет імені І. Я. Горбачевського, Тернопіль, Україна. E-mail: dub_aih@tdmu.edu.ua, ORCID 0000-0002-6945-2422.

Демид А. Є. - канд. хім., н., доцент кафедри загальної хімії, Тернопільський національний медичний університет імені І. Я. Горбачевського, Тернопіль, Україна. E-mail: demyd@tdmu.edu.ua, ORCID 0000-0001-8275-1307.

Грошовий Т. А. - д. фрармац. н., професор, завідувач кафредри управління та економіки фрармації з технологією ліків, Тернопільський національний медичний університет імені І. Я. Горбачевського, Тернопіль, Україна. E-таї: grochovuy@tdmu.edu.ua, ORCID 0000-0002-6427-2158.

Кліщ І. М. - д. біол. н., проф., профресор кафедри фрункціональної і лабораторної діагностики, Тернопільський національний медичний університет імені І. Я. Горбачевського, Тернопіль, Україна. E-mail: klishch@tdmu.edu.ua, ORCID 0000-0001-6226-4296.

\section{Information about the authors}

Vronska L. V. - PhD (Chemistry), Associate Professor of the Pharmacy Department, I. Horbachevsky Ternopil National Medical University, Ternopil, Ukraine. E-mail: vronska_liudmyla@ukr.net, ORCID 0000-0002-7223-6966.

Dub A. I. - PhD-student, assistant of the Pharmacy Management, Economics and Technology Department, I. Horbachevsky Ternopil National Medical University, Ternopil, Ukraine. E-mail: dub aih@tdmu.edu.ua, ORCID 0000-0002-6945-2422.

Demyd A. Ye. - PhD (Chemistry), Associate Professor of the General Chemistry Department, I. Horbachevsky Ternopil National Medical University, Ternopil, Ukraine. E-mail: demyd@tdmu.edu.ua, ORCID 0000-0001-8275-1307.

Hroshovyi T. A. - DS (Pharmacy), Professor, Chief of the Pharmacy Management, Economics and Technology Department, I. Horbachevsky Ternopil National Medical Head University, Ternopil, Ukraine. E-mail: grochovuy@tdmu.edu.ua, ORCID 0000-0002-6427-2158.

Klishch I. M. - DS (Biology), Professor of the Functional and Laboratory Diagnostics Department, I. Horbachevsky Ternopil National Medical University, Ternopil, Ukraine. E-mail: klishch@tdmu.edu.ua, ORCID 0000-0001-6226-4296. 